\title{
POLICE-OBTAINED EVIDENCE AND THE CONSTITUTION: DISTINGUISHING UNCONSTITUTIONALLY OBTAINED EVIDENCE FROM UNCONSTITUTIONALLY USED EVIDENCE $\uparrow$
}

\author{
Arnold H. Loewy*
}

The exclusion of police-obtained evidence at a criminal trial can be justified by one of two theories. Under one theory, evidence is excluded because the police have unconstitutionally obtained the evidence and exclusion is thought desirable to deter such police behavior in the future by precluding a substantial benefit from such misconduct. Under the other theory, the evidence is excluded because the Constitution guarantees the defendant a procedural right to exclude the evidence. ${ }^{1}$ The former theory focuses on the constitutional impropriety of obtaining the evidence, while the latter theory's focus is on the constitutional impropriety of using that evidence at trial. Obviously, one's choice of theory will affect the occasions upon which evidence is excluded. It will also determine whether the officer who obtained the evidence is vulnerable to a lawsuit by the person from whom it was obtained.

The thesis of this article is that neither rationale is universally appropriate because sometimes the Court is faced with unconstitutionally obtained evidence and other times it is faced with evidence whose use is forbidden by the Constitution. I will categorize various types of police-obtained evidence and explore the ramifications of treating a particular piece of evidence one way or the other.

The article will consider four different types of police-obtained evidence: evidence obtained from an unconstitutional search and

†๑ 1989 Amold H. Loewy.

* Professor, University of North Carolina School of Law. J.D. 1963, Boston University; L.L.M. 1964, Harvard. - Ed. The author would like to thank Alicia Davenport and David Gilpin for their dedicated research assistance in the preparation of this article, Professors Robert Mosteller of Duke University and Yale Kamisar of Michigan for their comments on an earlier draft, several professors from the University of North Carolina Law School faculty for their comments during a presentation of this paper, and the University of North Carolina Law Center for its financial support.

1. A third theory sometimes advanced is that of judicial integrity. In recent years, however, a majority of the Court has not taken this theory seriously. See, e.g., United States v. Leon, 468 U.S. 897, 921 n.22 (1984). 
seizure, ${ }^{2}$ evidence obtained from a Mirand $^{3}$ violation, confessions and lineup identifications obtained in violation of the sixth amendment right to counsel, ${ }^{4}$ and coerced confessions. My conclusions are that evidence obtained from an unconstitutional search and seizure is excluded because of the police misconduct by which it was obtained. On the other hand, evidence obtained from a Miranda violation is (or ought to be) excluded because use of that evidence compromises the defendant's procedural right not to be compelled to be a witness against himself. 5 Confessions and lineup identifications obtained after the right to counsel has attached also are excluded for procedural reasons. Finally, all coerced confessions are excluded because procedurally their introduction violates the fifth amendment. Some coerced confessions are also excluded because of police misconduct in obtaining them. Ultimately, this article demonstrates that whether evidence is unconstitutionally obtained or unconstitutionally used ought to make a difference, and that the Court's frequent failure to think in these terms has caused it to overlook the differences.

\section{UNCONSTITUTIONAL SEARCHES AND SEIzURES}

The Supreme Court's fourth amendment exclusionary rule jurisprudence is fairly simple. ${ }^{6}$ The Court views the fourth amendment as a protection against unreasonable searches and seizures. It perceives the exclusionary rule to be a remedial device designed to implement that protection by deterring or reducing the incentive to conduct an

\footnotetext{
2. The fourth amendment to the U. S. Constitution reads:

The right of the people to be secure in their persons, houses, papers, and effects, against unreasonable searches and seizures, shall not be violated, and no Warrants shall issue, but upon probable cause, supported by Oath or affirmation, and particularly describing the place to be searched, and the persons or things to be seized.
}

U.S. CoNST. amend. IV.

3. Miranda v. Arizona, 384 U.S. 436 (1966).

4. "In all criminal prosecutions, the accused shall enjoy the right . . . to have the Assistance of Counsel for his defence." U.S. CONST. amend. VI.

5. "No person ... shall be compelled in any criminal case to be a witness against himself . ..." U.S. ConsT. amend. V.

6. This is not true of its substantive fourth amendment jurisprudence, which is anything but simple. See Coolidge v. New Hampshire, 403 U.S. 443, 483 (1971) ("Of course, it would be nonsense to pretend that our decision today reduces Fourth Amendment law to complete order and harmony. The decisions of the Court over the years point in differing directions and differ in emphasis. No trick of logic will make them all perfectly consistent."); Chimel v. Califomia, 395 U.S. 752, 755-60 (1968) (tracing the "hardly . . . unimpeachable line of authority" for search and seizure cases); Chapman v. United States, 365 U.S. 610, 618 (1961) (Frankfurter, J., concurring) (stating "[t]he course of true law pertaining to searches and seizures . . . has not - to put it mildly - run smooth"). See generally LaFave, Search and Seizure: "The Course of True Law . . . Has Not . . Run Smooth," 1966 U. ILL. L.F. 255; Amsterdam, Perspectives on the Fourth Amendment, 58 MINN. L. REV. 349 (1974). 
unlawful search or seizure. ${ }^{7}$ Although powerful arguments have been made against this approach, ${ }^{8}$ it is fundamentally sound for the reasons that follow. ${ }^{9}$

First and foremost, fourth amendment rights are substantive as opposed to procedural rights. Like freedom of speech, ${ }^{10}$ the right to bear arms, ${ }^{11}$ and especially the immunity from having soldiers quartered in one's home, ${ }^{12}$ freedom from unreasonable searches and seizures is a substantive protection available to all inhabitants of the United States, whether or not charged with crime. The right thus differs from protections under most of the fifth amendment and all of the sixth amendment, which refer to persons charged with crime or "the accused."13

Fear of unreasonable searches and seizures rather than concern about criminal trials produced the fourth amendment. The most famous English ${ }^{14}$ and colonial ${ }^{15}$ search and seizure cases involved innocent citizens. It was their plight that inspired people like James Otis to demand protection against unreasonable searches and seizures. ${ }^{16}$

7. See Stone v. Powell, 428 U.S. 465,486 (1976); United States v. Calandra, 414 U.S. 338, 347-48 (1974); Linkletter v. Walker, 381 U.S. 618, 636-37 (1965).

8. See United States v. Calandra, 414 U.S. at 355-67 (Brennan, J., dissenting); Kamisar, Does (Did) (Should) the Exclusionary Rule Rest on a "Principled Basis" Rather Than an "Empirical Proposition"?, 16 CREIGHTON L. REv. 565 (1983); Schrock \& Welsh, Up from Calandra: The Exclusionary Rule as a Constitutional Requirement, 59 MiNN. L. REV. 251 (1974).

9. At least, it is sound in principle. For the reasons that follow, it is not always sound in application. See infra text accompanying notes $26-43$.

10. U.S. Const. amend. I.

11. U.S. CoNST. amend. II.

12. U.S. ConsT. amend. III.

13. The fifth amendment to the United States Constitution reads:

No person shall be held to answer for a capital, or otherwise infamous crime, unless on a presentment or indictment of a Grand Jury ... nor shall any person be subject for the same offence to be twice put in jeopardy of life or limb; nor shall be compelled in any criminal case to be a witness against himself .... .

U.S. CONST. amend. V (emphasis added). The sixth amendment states:

In all criminal prosecutions, the accused shall enjoy the right to a speedy and public trial ... and to be informed of the nature and cause of the accusation; to be confronted with the witnesses against him; to have compulsory process for obtaining witnesses in his favor, and to have the Assistance of Counsel for his defence.

U.S. CONST. amend. VI (emphasis added).

14. See Wilkes v. Wood, Lofft 1, 98 Eng. Rep. 489 (K.B. 1763); Entick v. Carrington, 2 Wils. 275, 19 Howell's State Trials 1030, 95 Eng. Rep. 807 (K.B. 1765).

15. See Paxton's Case, Mass. Bay Rep. (Quincy) 51 (1761). See generally R. RutLANd, THE BIRTH OF THE BILL OF RIGHTS, 1776-1791 (1955). Rutland discusses a Boston town meeting at which "A List of Infringements and Violations of Rights" was drawn up which "alluded to a number of personal rights which had allegedly been violated by agents of the crown. The list included complaints against the writs of assistance which had been employed by royal officers in their searches for contraband. The Bostonians complained that 'our houses and even our bed chambers are exposed to be ransacked, our boxes, chests, and trunks broke open, ravaged and plundered by wretches, whom no prudent man would venture to employ even as menial servants." " Id. at 25.

16. See John Adams' "abstract" of James Otis' argument against the Writ of Assistance in Paxton's Case, Mass. Bay Rep. (Quincy) 51 (1761): "I will to my dying day oppose, with all the 
Indeed, because searches and seizures are permitted when an independent magistrate has determined that there is probable cause to find particular evidence of guilt at the place to be searched, ${ }^{17}$ I have argued that the purpose of the fourth amendment is to protect the innocent and that the guilty are merely necessary incidental beneficiaries of the innocent person's right not to be searched. ${ }^{18}$ However that issue might ultimately be resolved, ${ }^{19}$ the fourth amendment, in language and origin, is clearly substantive in that it is concerned with obtaining rather than using evidence. Therefore, the Court was correct in holding the exclusionary rule to be simply a remedial device designed to make the substantive right more meaningful ${ }^{20}$ rather than an independent procedural right. ${ }^{21}$

Some critics have contended that the review of the fourth amendment renders its rights second class. ${ }^{22}$ The fallacy of this critique is that it attempts to compare substantive rights with procedural rights. Procedural rights are supposed to exclude evidence. Substantive rights need not. Consequently, fourth amendment rights should be deemed different from, but not less important than, the procedural rights protected by the fifth, sixth, and fourteenth amendments. By way of comparison, first and third amendment rights are substantive,

powers and faculties God has given me, all such instruments of slavery on the one hand, and villainy on the other, as this writ of assistance is." M. SMITH, THE WRITS OF ASSISTANCE CASE 552 (1978) (from Adams' "Abstract" in the Massachusetts Spy of April 29, 1773). Otis pronounced the writs of assistance "the worst instrument of arbitrary power, the most destructive of English liberty, and the fundamental principles of law, that ever was found in an English law book . ..." Boyd v. United States, 116 U.S. 616, 625 (1886) (quoting T. CoOLEY, CoNsTITUTIONAL LimitATIONS 368 (5th ed. 1883)). See also R. RUTLAND, supra note 15. "Blackstone's comment that a general warrant 'to apprehend all persons suspected, without naming or particularly describing any person in special, is illegal and void for its uncertainty' was regarded by Americans as a correct view of the matter." Id. at 11 (quoting 4 W. BLACKSTONE, COMMENTARIES *291).

17. Cf. Warden v. Hayden, 387 U.S. 294, 300-10 (1967) (evidence otherwise properly obtained is not to be excluded because it is "mere evidence" to which the government cannot assert a superior proprietary interest).

18. See Loewy, The Fourth Amendment as a Device for Protecting the Innocent, $81 \mathrm{MICH} . \mathrm{L}$. REV. 1229 (1983).

19. For a recent criticism, see Maclin, Constructing Fourth Amendment Principles from the Government Perspective: Whose Amendment Is It, Anyway?, 25 AM. CRIM. L. REv. 669, 705-18 (1988).

20. See supra note 7.

21. The argument that the fourth and fifth amendments "run almost into each other," Boyd v. United States, 116 U.S. 616, 630 (1886), although occasionally invoked, see Mapp v. Ohio, 367 U.S. 643, 646 (1961); 367 U.S. at 662 (Black, J., concurring), has been discredited, see Andresen v. Maryland, 427 U.S. 463, 471-77 (1976). Indeed, it is flatly inconsistent with the Court's willingness to allow the introduction of evidence from reasonable searches, which is likely to be at least as incriminating as evidence obtained from unreasonable searches and seizures.

22. See Allen, The Wolf Case: Search and Seizure, Federalism, and the Civil Liberties, 45 ILL. L. REV. 1, 29 (1950); Kamisar, supra note 8, at 632-33, 640; see also infra text accompanying notes 137-39. 
but nobody would deem them second class. ${ }^{23}$

On the other hand, searches and seizures are usually employed to obtain evidence of crime. Consequently, it makes good sense from a utilitarian perspective to engraft an exclusionary rule onto the fourth amendment. Although the jury is still out on how well the exclusionary rule works as a deterrent, ${ }^{24}$ it is counter-intuitive to deny the disincentive character of the rule. Surely, a police officer who knows that unconstitutionally obtained evidence will be admissible would have an incentive that is absent in an officer who knows that such evidence is inadmissible.

Given that the fourth amendment wrong is obtaining evidence, the Court must consider the circumstances under which the exclusionary rule should be applied. The Court's response has been to balance the costs of the exclusionary rule against its benefits. ${ }^{25}$ While the cost/ benefit approach is sound, the balance actually struck by the Court is another matter. By regularly decrying the high cost of the exclusionary rule, the Court has failed to apply it to situations in which it could have discouraged unconstitutional conduct.

For example, in United States v. Payner, ${ }^{26}$ the Court refused to suppress evidence illegally seized from a banker's briefcase which the government used against Payner. The evidence was stolen from banker Wolstencroft's briefcase while his attention was diverted by a woman, hired by the government for that purpose. Because the government sought evidence against Wolstencroft's clients and not Wolstencroft himself, it felt free to violate Wolstencroft's fourth amendment rights, secure in the knowledge that any evidence obtained

23. Arguably, the second amendment, which is also substantive, is somewhat second class. See, e.g., United States v. Miller, 307 U.S. 174 (1939) (adopting a collective rights approach to the amendment, whereby it protects the interests of the state and not individual citizens). The treatment of this amendment, however, does not suggest that all substantive amendments are second class.

24. There is little empirical evidence available on the effectiveness of the exclusionary rule as a deterrent, and what little there is is not conclusive. See Canon, The Exclusionary Rule: Have Critics Proven That It Doesn't Deter Police?, 62 JudICATURE 398 (1979) (arguing that studies so far have been inconclusive); Schlesinger, The Exclusionary Rule: Have Proponents Proven That It Is a Deterrent to Police?, 62 JuDICATURE 404 (1979) (arguing that most studies question the rule's effectiveness and that proponents of the rule have not met their burden of proving that it is an effective deterrent). See generally Exclusionary Rule in Criminal Trials: Oversight Hearings Before the Subcomm. on Criminal Justice of the House Comm. on the Judiciary, 98th Cong., 1st Sess. (1983) (examining the operation of the exclusionary rule as an enforcement mechanism for the fourth amendment with regard to its costs to society and its effectiveness as a deterrent, and exploring alternate methods of enforcing fourth amendment rights). But cf. Oaks, Studying the Exclusionary Rule in Search and Seizure, 37 U. CHI. L. REV. 665, 756 (1970) (the exclusionary rule is not an effective deterrent and should be replaced with a tort remedy).

25. See United States v. Calandra, 414 U.S. 338 (1974); Rakas v. Illinois, 439 U.S. 128 (1978); Stone v. Powell, 428 U.S. 465 (1976); United States v. Leon, 468 U.S. 897 (1984).

26. 447 U.S. 727 (1980). 
would be admissible against Wolstencroft's clients. Although the Court stated that "[n]o court should condone the unconstitutional and possibly criminal behavior of those who planned and executed this "briefcase caper," "27 it declared that such "wilfully lawless activities undertaken in the name of law enforcement" must be balanced "against the considerable harm that would flow from indiscriminate application of an exclusionary rule." 28 By admitting the evidence in this type of case, the Court has created a powerful incentive not to take the substantive rights guaranteed by the fourth amendment seriously. ${ }^{29}$

The Court's jurisprudence suffers from a vacillating perception of who the beneficiary of the exclusionary rule ought to be. At times the Court takes an extremely individualistic or "atomistic view" 30 of the fourth amendment, holding that only those whose personal fourth amendment rights have been violated may invoke the exclusionary rule. ${ }^{31}$ In other cases, the Court has stressed the collective rather than individual nature of the exclusionary remedy. ${ }^{32}$ Defendants in these cases have been denied the exclusionary remedy because, in the opinion of the Court, the deterrent or disincentive value of the remedy was not worth the cost of exclusion. ${ }^{33}$

Were the Court to focus exclusively on the collective or regulatory

27. Payner, 447 U.S. at 733.

28. Payner, 447 U.S. at 734.

29. See Loewy, A Modest Proposal for Fighting Organized Crime: Stop Taking the Fourth Amendment So Seriously, 16 RuTGERS L.J. 831 (1985).

30. The phrase is Professor Anthony Amsterdam's. See Amsterdam, supra note 6, at 367.

31. See Rakas v. Illinois, 439 U.S. 128 (1978); Rawlings v. Kentucky, 448 U.S. 98 (1980).

32. See United States v. Calandra, 414 U.S. 338 (1974); United States v. Janis, 428 U.S. 433 (1976).

33. Professor Donald Doemberg has attributed this "bifurcated approach" to "the Court's dissatisfaction with the exclusionary rule." Doernberg, "The Right of the People": Reconciling Collective and Individual Interests Under the Fourth Amendment, 58 N.Y.U. L. REv. 259, 288 (1983). "[T]he problem of today's fourth amendment jurisprudence is that the Court is unwilling to prescribe the medicament in the cases where it is needed because it dislikes the side effects. The result is judicial condonation of lawless governmental activity ...." Id. at 294-95 (footnotes omitted). His theory is that the Court regards the exclusionary rule as one of many possible remedies, and thus chooses to apply it only in a narrow range of circumstances; however, Doernberg sees this approach as a refusal by the Court to "tailor its remedies" to match the range of fourth amendment protection that it has acknowledged. Id. at 288 . By recognizing an individual right with respect to questions of standing and then applying a collective remedy designed to protect society by deterring unlawful police conduct, the Court is "using two analytically distinct approaches to analyze fourth amendment cases" which are "fundamentally at war with each other." Id. at 285. Doernberg proposes that the Court alter its standing doctrine by resurrecting the target theory of standing mentioned in Jones v. United States, 362 U.S. 257 (1960). This would have a dual effect. It would allow the exclusionary rule to serve as an individual remedy for violations of the individual right already acknowledged, Doernberg, supra, at 290, and it would expand the boundaries of the collective remedy to those of the collective right, "penalizing government conduct which violates the fourth amendment in all, or substantially all, of the cases in which it occurs." Id. at 296 (footnote omitted). 
nature of the exclusionary rule, its jurisprudence would improve considerably. Such an approach would recognize the substantive nature of the right which is violated by the search rather than the introduction of illegal evidence at an individual's trial. The Court has conceded that the substantive right violated by an unconstitutional search or seizure cannot be restored by the exclusionary rule: "The ruptured privacy of the victims' homes and effects cannot be restored. Reparation comes too late."34 Furthermore, unlike the fifth or sixth amendments, the fourth amendment speaks of "[t]he right of the people."35 When one couples this language with the historic societal concern about inadequate controls on government power to search, ${ }^{36}$ a jurisprudence that seriously seeks to avoid incentives for unlawful searches and seizures becomes singularly appropriate.

A good analogy is the establishment of religion clause of the first amendment. ${ }^{37}$ Because the establishment clause is thought to be a collective protection, anybody who is economically hurt by a law that respects the establishment of religion may challenge that law even though her own religious freedom is in no way compromised. ${ }^{38}$ Similarly, anybody against whom unconstitutionally obtained evidence is introduced ought to be able to challenge the evidence, even if his fourth amendment rights were not violated. ${ }^{39}$ Such a rule applies in

34. Linkletter v. Walker, 381 U.S. 618, 637 (1965).

35. "The right of the people to be secure ... against unreasonable searches and seizures, shall not be violated ...." U.S. CONST. amend. IV (emphasis added); see Amsterdam, supra note 6, at 367.

36. That societal concern is evidenced by the observation of Justice Jackson:

Uncontrolled search and seizure is one of the first and most effective weapons in the arsenal of every arbitrary government. And one need only briefly to have dwelt and worked among a people possessed of many admirable qualities but deprived of these rights to know that the human personality deteriorates and dignity and self-reliance disappear where homes, persons and possessions are subject at any hour to unheralded search and seizure by the police. Brinegar v. United States, 338 U.S. 160, 180-81 (1949) (Jackson, J., dissenting); see supra notes 14-16.

37. "Congress shall make no law respecting an establishment of religion ...." U.S. CoNST. amend. I.

38. See McGowan v. Maryland, 366 U.S. 420, 430-31 (1961); Engel v. Vitale, 370 U.S. 421, $430-31$ (1962). On the other hand, a claim based on the free exercise clause of the first amendment may be made only by one whose personal religious freedom has been infringed. McGowan, 366 U.S. at 429.

39. Perhaps there should be an exception when the victim of a search would be hurt by the exclusionary rule. For example, when the police conduct an unlawful search of a burglary victim's house and find evidence against the suspect, excluding the evidence may be too much for the innocent victim of both the search and the burglary to bear. But cf. People v. Jager, $145 \mathrm{Cal}$. App. 2d 792, 303 P.2d 115 (1956). 
Louisiana ${ }^{40}$ and used to apply in California. ${ }^{41}$ The Supreme Court, however, values conviction of criminals more than fourth amendment disincentives. Consequently, it has neither bound states to this broadened standing rule ${ }^{42}$ nor permitted the rule's use in federal courts. ${ }^{43}$

Finally, because the exclusionary rule is designed as a disincentive to conducting unlawful searches and seizures, it should never be applied when the search and seizure is lawful. This apparently obvious proposition must be stated because both the judiciary ${ }^{44}$ and academy ${ }^{45}$ have argued that certain types of searches ought to be lawful, but that evidence obtained from them should be inadmissible. These arguments focus on searches such as automobile inventory searches ${ }^{46}$ or

\section{The Louisiana Constitution states:}

Every person shall be secure in his person, property, communications, houses, papers, and effects against unreasonable searches, seizures, or invasions of privacy. No warrant shall issue without probable cause supported by oath or affirmation, and particularly describing the place to be searched, the persons or things to be seized, and the lawful purpose or reason for the search. Any person adversely affected by a search or seizure conducted in violation of this Section shall have standing to raise its illegality in the appropriate court.

LA. ConsT. art. I, $\S 5$ (emphasis added).

41. The Supreme Court of California did not agree with the theory that evidence seized in violation of the fourth amendment should be excluded in order to "provide a remedy for a wrong done to the defendant, and that accordingly, if the defendant has not been wronged he is entitled to no remedy." People v. Martin, 45 Cal. 2d 755, 759-60, 290 P.2d 855, 857 (1955). Instead, the court adopted the exclusionary rule because " "other remedies have completely failed to secure compliance with constitutional provisions on the part of police officers with the attendant result that the courts under the old rule have been constantly required to participate in, and in effect condone, the lawless activities of law enforcement officers." " $45 \mathrm{Cal}$. 2d at 760, 290 P.2d at 857 (quoting People v. Cahan, 44 Cal. 2d 434, 445, 282 P.2d 905, 911-12 (1955)). The court in Martin declared that the defendant's "right to object to the use of the evidence must rest, not on a violation of his own constitutional rights, but on the ground that the government must not be allowed to profit by its own wrong and thus encouraged in the lawless enforcement of the law." $45 \mathrm{Cal} .2 \mathrm{~d}$ at 761,290 P.2d at 857.

The California Constitution has since been amended to overrule Martin. The amendment, adopted in 1982, provided that "relevant evidence shall not be excluded in any criminal proceeding," CAL. CONST. art. I, § 28(d), and is said to have "referendummed into oblivion" the Martin rule. LaFave, Being Frank About the Fourth: On Allen's "Process of 'Factualization' in the Search and Seizure Cases," 85 MICH. L. REv. 427, 432 (1986).

42. See, e.g., Rakas v. Illinois, 439 U.S. 128 (1978).

43. An extreme example is United States v. Payner, 447 U.S. 727 (1980), discussed supra at text accompanying notes 26-28. See generally Beale, Reconsidering Supervisory Power in Criminal Cases: Constitutional and Statutory Limits on the Authority of the Federal Courts, 84 CoLUM. L. REV. 1433 (1984).

44. The dissent of Judge Ely, in United States v. Mitchell, 458 F.2d 960 (9th Cir. 1972), suggests that an "effective compromise" would be "to permit extensive inventory searches of seized vehicles, so as fully to protect the police, but to forbid, over the objection of one having standing, the use of any item seized in the search as evidence against the objector." 458 F.2d at 966.

45. See Amsterdam, supra note 6, at 437. Professor Amsterdam proposes, as one of three possible "curbs" against abuses of the stop and frisk power, that a rule be made which excludes from evidence everything that an officer finds in the course of a stop-and-frisk except weapons.

46. See, e.g., South Dakota v. Opperman, 428 U.S. 364 (1976); Colorado v. Bertine, 479 U.S. 367 (1987). 
stop and frisks ${ }^{47}$ which are permitted on less than probable cause because of the policeman's interest in protecting himself from claims for lost property (inventory search) or weapons (stop and frisk). Nevertheless, the argument continues, a police officer might conduct such a search with the ulterior motive of finding evidence of crime. By rendering such evidence inadmissible, no improperly motivated search would occur, and privacy would only be breached when the officer really intended to protect property or frisk for weapons.

The problem with this argument is that it provides a remedy when there may not in fact have been a violation. The exclusionary remedy is justified only when an underlying right has been violated. If an improper motive is established in one of these types of cases, the search would be unconstitutional. 48 If such a motive cannot be established, it seems unnecessarily draconian to exclude the evidence because of the theoretical possibility that it might have been obtained from a search conducted with impermissible motives. More importantly, such a rule would mean that if two people are subjected to the same type of search, only the guilty one would have a remedy. For example, assume that Bill and George are each frisked because a police officer reasonably suspects that they are armed and dangerous. The officer feels a hard weapon-like object on Bill's person, which upon inspection turns out to be a bottle containing heroin. George is also subjected to the indignity of a frisk, ${ }^{49}$ which, because he is an honest law-abiding citizen, turns up nothing. Under the proposed exclusionary rule, the heroin could not be introduced against Bill, but because the search was lawful George would have no recourse against the police officer. ${ }^{50}$ Such a rule would be appropriate if the focus of the constitutional

47. See, e.g., Terry v. Ohio, 392 U.S. 1 (1968).

48. See Sibron v. New York, 392 U.S. 40, 64-66 (1968); Opperman, 428 U.S. at 376; Bertine, 479 U.S. at 375.

49. The indignity that might be felt could be that described in Terry v. Ohio: "The officer must feel with sensitive fingers every portion of the prisoner's body. A thorough search must be made of the prisoner's arms and armpits, waistline and back, the groin and area about the testicles, and entire surface of the legs down to the feet.' " 392 U.S. at 17, n.13 (quoting Priar \& Martin, Searching and Disarming Criminals, 45 J. CRIM. L., CRIMINology \& Police SCI. 481 (1954)). After describing this procedure, the Court concluded that "it is simply fantastic to urge that such a procedure [as a stop and frisk] performed in public by a policeman while the citizen stands helpless, perhaps facing a wall with his hands raised, is a 'petty indignity." " 392 U.S. at 16-17.

50. Terry v. Ohio, 392 U.S. 1 (1968), in which Officer McFadden became suspicious of Terry, Chilton, and Katz because they were conducting a "casual and oft-repeated reconnaissance" of a store window, is a good example. 392 U.S. at 6. Officer McFadden suspected them of "'casing a job, a stick-up," " and added that he feared "'they may have a gun.'" 392 U.S. at 6. Officer McFadden'approached the men, and when they "'mumbled something" " in response to his inquiries, Officer McFadden patted down the outside of Terry's clothing and found a pistol. Officer McFadden then proceeded to pat down the outer clothing of Chilton and found another revolver. He next checked Katz in the same way but he found no weapons. 392 U.S. at 7. Under the 
guarantee were against the use of evidence because the wrong would consist of its use at trial. ${ }^{51}$ Where, however, the constitutional provision is primarily concerned with obtaining evidence, such a rule is entirely inappropriate. Here, the exclusionary remedy should apply only when evidence was acquired by police misconduct.

\section{MIRANDA VIOLATIONS}

Compared to Miranda, the rationale for the fourth amendment exclusionary rule is a paragon of simplicity. It is not clear whether the Court disallows confessions obtained in violation of Miranda because they were obtained improperly or because their use is improper. Language in both Miranda ${ }^{52}$ and its progeny ${ }^{53}$ can be found to support either conclusion. Miranda's holding, however, focuses on the impropriety of use: "Our holding . . . briefly stated ... is this: The prosecu-

proposed rule, Katz would have no recourse against McFadden, but Terry and Chilton would go free.

51. See infra Sections II, III, and IV.

52. The following statements suggest that obtaining the confession is improper: "[W]e hold that when an individual is taken into custody or otherwise deprived of his freedom by the authorities in any significant way and is subjected to questioning, the privilege against self-incrimination is jeopardized." 384 U.S. at 478 . "The current practice of incommunicado interrogation is at odds with one of our Nation's most cherished principles - that the individual may not be compelled to incriminate himself." 384 U.S. at 457-58. "In fact, the Government concedes . . . "[w]e have no doubt ... that it is possible for a suspect's Fifth Amendment right to be violated during in-custody questioning by a law-enforcement officer." 384 U.S. at 463 (quoting Brief for the United States at 28, Westover v. United States, 384 U.S. 436 (1966) (No. 761) (companion case to Miranda)). Other language suggests that the Court's only concern was the use of the confessions: "The warnings required and the waiver necessary in accordance with our opinion today are ... prerequisites to the admissibility of any statement made by a defendant." 384 U.S. at 476 . The Court did not allow a distinction to be drawn between exculpatory and inculpatory statements for purposes of requiring the warnings, as exculpatory statements "are incriminating in any meaningful sense of the word and may not be used without the full warnings and effective waiver required for any other statement." 384 U.S. at 477 (emphasis added). In summarizing, the Court stated that "unless and until such warnings and waiver are demonstrated by the prosecution at trial, no evidence obtained as a result of interrogation can be used against him." 384 U.S. at 479 .

53. The Court in Michigan v. Tucker, 417 U.S. 433 (1974), reviewed the Miranda decision and found that "the Court in Miranda, for the first time, expressly declared that the Self-Incrimination Clause was applicable to state interrogations at a police station, and that a defendant's statements might be excluded at trial despite their voluntary character under traditional principles." 417 U.S. at 443 . Although this sounds like the Court is concerned with obtaining the confession and enforcing that concern with an exclusionary rule, the Court went on to describe Miranda as holding that "statements taken in violation of the Miranda principles must not be used to prove the prosecution's case at trial." 417 U.S. at 445 (emphasis added).

The Court also reviewed Miranda in New York v. Quarles, 467 U.S. 649 (1984), where it found that "[t]he Miranda decision was based in large part on this Court's view that the warnings which it required police to give to suspects in custody would reduce the likelihood that the suspects would fall victim to constitutionally impermissible practices of police interrogation in the presumptively coercive environment of the station house." 467 U.S. at 656 (emphasis added). On the other hand, in announcing its holding, the Court said: "We hold that on these facts there is a 'public safety' exception to the requirement that Miranda wamings be given before a suspect's answers may be admitted into evidence . . ." 467 U.S. at 655 (emphasis added). 
tion may not use statements . . . stemming from custodial interrogation of the defendant unless it demonstrates the use of procedural safeguards effective to secure the privilege against self-incrimination." 54 Because of the overall ambiguity of the Court's language, however, coupled with its failure to focus on the unconstitutionally obtained/unconstitutionally used dichotomy, the "holding" language does not necessarily settle the issue.

Nevertheless, for the reasons that follow, I will argue that the $\mathrm{Mi}$ randa doctrine ought to focus on the impropriety of using rather than obtaining the evidence. Put differently, Miranda should be viewed as a trial-rights case rather than a police-practices case. Under this reasoning, courts should not care whether or not Miranda is violated so long as no evidence obtained from the violation is introduced against the person from whom it was obtained. Similarly, no police officer should be subject to a law suit for obtaining a confession in violation of Miranda. 55

For purposes of discussion, consider the California case of People v. Varnum, ${ }^{56}$ in which the state learned the location of a gun from questioning Mr. and Mrs. Jackson, two of Varnum's apparent accomplices, in a manner inconsistent with Miranda. ${ }^{57}$ At that time, under California law, Varnum had standing to challenge the introduction of evidence obtained in violation of another's constitutional rights. ${ }^{58}$ Consequently, Varnum's ability to have the evidence excluded from his trial turned on what constituted a violation of the Jacksons' $M i$ randa rights. If obtaining a statement from the Jacksons without $M i$ randa warnings violated their constitutional rights, a court could not admit the evidence against Varnum. On the other hand, if the Jacksons' Miranda rights were not violated unless and until the evidence was used against them, Varnum could not object to the use of the evidence against him.

The California Supreme Court, per Chief Justice Traynor, upheld

54. 384 U.S. at 444 (emphasis added).

55. See Bennett v. Passic, 545 F.2d 1260, 1263 (10th Cir. 1976); Hampton v. Gilmore, 60 F.R.D. 71 (E.D. Mo. 1973), affd., 486 F.2d 1407 (8th Cir. 1973); Ambrek v. Clark, 287 F. Supp. 208 (E.D. Pa. 1968).

56. 66 Cal. 2d 808, 427 P.2d 772 (1967).

57. The police officers had conducted a" "fruitless search for the gun throughout the building where the Jacksons lived. They then prevailed upon Jackson, who was in jail and had confessed, to telephone his wife, who was in the women's jail, and ask her to reveal the hiding place of the gun. Mrs. Jackson said it was in the fuse box in the hallway of the apartment building, where an officer later found it. The officers thus learned of the hiding place of the gun from both Jackson and his wife who had not been advised of their constitutional rights." $66 \mathrm{Cal} .2 \mathrm{~d}$ at $811,427 \mathrm{P.2d}$ at 775 .

58. See supra note 41. 
Varnum's conviction, apparently accepting that Miranda protected against the use of illegal evidence. It noted that "[t]he basis for the warnings required by Miranda is the privilege against self-incrimination ..., and that privilege is not violated when the information elicited from an unwarned suspect is not used against him." 59 In dissent, Justice Peters argued that it is

"unlawful" to interrogate a suspect without giving him the required warnings from the very moment of the first question. The right of privacy referred to in Escobedo ${ }^{60}$ and Miranda has been violated the moment interrogation starts. The fact that the most important sanction imposed for violating that right of privacy is inadmissibility of the confession into evidence, and that the defendant cannot complain in his criminal trial unless the confession is introduced, does not make the interrogation lawful. The same can be said about an unlawful search and seizure; yet there is no doubt that the unlawful search is unlawful when committed, and not when the fruits are introduced into evidence. The one thing made crystal clear by Escobedo and certainly by the explanation of that case in Miranda is that it is unlawful to interrogate without giving the required warnings. ${ }^{61}$

In the remainder of this section, I will explain why Chief Justice Traynor's understanding of Miranda is correct and Justice Peters' analogy to the fourth amendment misses the mark.

Because the primary purpose of Miranda is to implement the privilege against self-incrimination, an obvious starting point is the language of that constitutional provision: "No person . . . shall be compelled in any criminal case to be a witness against himself . . ."62 The language indicates concern with the use of evidence at a criminal trial. It is not enough that disclosure of the information subjects an individual to public humiliation. Some might argue that since one can invoke the fifth amendment in noncriminal proceedings the amendment protects against any suffering associated with the revelation of damaging facts. As a result, Miranda rights might be thought violated anytime police force disclosure of damaging evidence. Admittedly, the amendment has been raised in noncriminal proceedings such as civil, ${ }^{63}$ administrative, ${ }^{64}$ or legislative proceedings. ${ }^{65}$ But such invoca-

59. 66 Cal. 2d at 812, 427 P.2d at 775 (citing Murphy v. Waterfront Commn., 378 U.S. 52, 78-79 (1964)).

60. Referring to Escobedo v. Illinois, 378 U.S. 475 (1964), a pre-Miranda case, which held a confession obtained in the absence of counsel to be inadmissible because of the sixth amendment's guarantee of counsel.

61. 66 Cal. $2 \mathrm{~d}$ at 817,427 P.2d at 778-79.

62. U.S. CoNST. amend. V (emphasis added).

63. "The privilege is not ordinarily dependent upon the nature of the proceeding in which the testimony is sought or is to be used. It applies alike to civil and criminal proceedings, wherever the answer might tend to subject to criminal responsibility him who gives it." McCarthy v. Andstein, 266 U.S. 34, 40 (1924). 
tion is allowed only because without it, the statements could be subsequently introduced in a criminal proceeding. If a witness receives immunity from use of the statements, or anything derived therefrom, in a subsequent criminal trial, the witness may be compelled to testify in a noncriminal proceeding. ${ }^{66}$ Consequently, it is not accurate to say that the fifth amendment is applicable to noncriminal proceedings as such.

It is sometimes argued that the fifth amendment should be construed more broadly. Justice Peters, for example, deemed it to be part of a general right of privacy. Such a right of privacy would be violated anytime police illegally obtained damaging information. A similar argument was made and rejected by the Supreme Court many years ago in Brown v. Walker. ${ }^{67}$ In Brown, a grand jury witness invoked the privilege against self incrimination in regard to a crime for which he had been granted complete immunity. ${ }^{68}$ Justice Field, in dissent, would have found for the witness: "The [fifth] amendment also protects him from all compulsory testimony which might expose him to infamy and disgrace, though the facts disclosed might not lead to a criminal prosecution."69 Directly confronting this argument, the Court held:

The design of the constitutional privilege is not to aid the witness in vindicating his character, but to protect him against being compelled to furnish evidence to convict him of a criminal charge. If he secures legal immunity from prosecution, the possible impairment of his good name is a penalty which it is reasonable he should be compelled to pay for the common good. ${ }^{70}$

Although an occasional Justice has lamented the failure of the Field view to gain acceptance, ${ }^{71}$ the Supreme Court has unequivocally ad-

64. I.C.C. v. Brimson, 154 U.S. 447 (1894).

65. Emspak v. United States, 349 U.S. 190 (1955); Quinn v. United States, 349 U.S. 155 (1955).

66.

[W] hen a witness is compelled by district court order to testify over a claim of the privilege, "the witness may not refuse to comply with the order on the basis of his privilege against self-incrimination; but no testimony or other information compelled under the order (or any information directly or indirectly derived from such testimony or other information) may be used against the witness in any criminal case, except a prosecution for perjury, giving a false statement, or otherwise failing to comply with the order."

Kastigar v. United States, 406 U.S. 441, $448-49$ (quoting 18 U.S.C. $§ 6002$ ).

67. 161 U.S. 591 (1896).

68. Complete or "transactional" immunity provides greater protection than is mandated by the Constitution. One who receives it cannot be prosecuted for the crime about which he testifies.

69. 161 U.S. at 631.

70. 161 U.S. at 605-06.

71. See, e.g., Douglas, J., dissenting in Ullmann v. United States, 350 U.S. 422, 448-55 (1956). 
hered to the view that a grant of immunity from prosecution precludes reliance on the privilege against self-incrimination. ${ }^{72}$

Consequently, it would seem clear that a legislature could authorize police officers to interrogate suspects without Miranda warnings, so long as it provided immunity from the use of any statements obtained therefrom. For example, the Court should have no difficulty upholding the following hypothetical statute:

An Act To Aid the Police in Obtaining Necessary Information

Whenever a police officer believes it to be necessary to obtain information from a person in custody, he may subject that person to custodial interrogation without warning the suspect of any of his rights. Neither the statement, nor any evidence derived from the statement, shall be admissible against the person so interrogated.

If such a statute would be constitutional, what about judicial immunity which accomplishes the same purpose? A possible analogue is the type of case in which a witness pleads the fifth amendment, and, despite the lack of statutory immunity, the judge orders her to testify. Under these circumstances, the defendant has a choice. If she refuses to testify and she is held in contempt, the appellate court will reverse her contempt conviction because of her privilege against self-incrimination. ${ }^{73}$ If she chooses to testify, however, she will be granted "use immunity" - that is, an appeals court would find use of that evidence unconstitutional. ${ }^{74}$ Although one could argue that the appellate court's reversal of the contempt conviction or the imposition of use immunity are merely remedies to redress the wrong committed by the lower court judge in compelling testimony, ${ }^{75}$ there is no basis for concluding that the fifth amendment interest is not completely vindicated. ${ }^{76}$ Rather, the court would have prevented or addressed the only constitutional wrong - the use of unconstitutional evidence to obtain a criminal conviction.

Furthermore, sound policy sometimes dictates obtaining statements from possible defendants with knowledge that the statements

72. Although the Court has occasionally explained the privilege against self-incrimination as one resting on concepts of privacy, see, e.g., Mapp v. Ohio, 367 U.S. 643, 655-57 (1961), nothing substantial has ever turned on that categorization.

73. Cf. Malloy v. Hogan, 378 U.S. 1 (1964).

74. See In re Folding Carton Antitrust Litig., 609 F.2d 867, 872 n.11 (7th Cir. 1979); cf. Adams v. Maryland, 347 U.S. 179 (1954).

75. See In re Corrugated Container Antitrust Litig., 644 F.2d 70, 78 \& n.13 (2d Cir. 1981).

76. A witness' fifth amendment interest may be vindicated either by silence or immunity. The state, and not the defendant, normally chooses which method it prefers. See generally Westen \& Mandell, To Talk, Balk, or To Lie: The Emerging Fifth Amendment Doctrine of the "Preferred Response," 19 AM. CRIM. L. REV. 521 (1982). When the state, through its judge, compels the witness to testify over her fifth amendment objections, however, it cannot complain about the witness' resulting immunity. 
cannot be used against that person. Such statements may well lead to evidence against a codefendant which would eliminate the need to seek a confession from the codefendant himself. Consider, for example, Dimmick v. State, ${ }^{77}$ a robbery case in which the prosecution's principal evidence was the victim's identification of Dimmick as one of the robbers. To buttress this identification, the prosecutor introduced the testimony of Lee Herman, who admitted committing the robbery with Dimmick. Herman's testimony was presumably compelled because of a confession given to police - a confession made after the victim failed to identify him and after the police ignored his request for counsel. "In the words of the police officer "the decision was made to go ahead and interview him [Herman] after he had requested an attorney full-well knowing that the confession could not be used against him but merely for the value of the confession against $\mathrm{Mr}$. Dimmick." "78 The entire Alaska Supreme Court considered questioning Herman after he had requested counsel to be a constitutional wrong which ought to be redressed. By a divided vote, however, the court affirmed Dimmick's conviction, concluding that the appropriate remedy ought to be a civil rights action by Herman against the police officers.

Contrary to the opinion of the Alaska Supreme Court, questioning Herman was not a violation of anybody's constitutional rights and should not give rise to a civil suit. Rather, it was an effort to corroborate the victim's identification of Dimmick by extrinsic evidence. The principal police alternative to Herman's eyewitness testimony would have been to seek a confession from Dimmick himself. Such conduct would run afoul of the too often ignored observation of Escobedo $v$. Illinois:

We have learned the lesson of history, ancient and modern, that a system of criminal law enforcement which comes to depend on the "confession" will, in the long run, be less reliable and more subject to abuses than a system which depends on extrinsic evidence independently secured through skillful investigation. ${ }^{79}$

Because, unlike fourth amendment rights, fifth amendment rights are not violated unless and until the statement is used against the person making it, the court should have commended, rather than condemned, the police, whose conduct led to a conviction based on extrinsic evidence $^{80}$ without relying on a confession from the defendant on trial. ${ }^{81}$

77. 473 P.2d 616 (Alaska 1970).

78. 473 P.2d at 619 .

79. 378 U.S. $478,488-89$ (1964).

80. Although Herman's confession would certainly not be "extrinsic" in his own case, it was "extrinsic" as to Dimmick.

81. The court concluded that the police had no probable cause to arrest Herman. 473 P.2d 
Another type of case in which the police might wish to question without (or inconsistent with) Miranda warnings is one in which they already have enough evidence against one defendant, but wish to obtain additional evidence against, or information about, his cohorts. For example, consider a hypothetical based on Oregon v. Elstad, 82 a case in which the police interrogated eighteen-year-old Michael Elstad about the burglary of a neighbor's house without giving him Miranda warnings. ${ }^{83}$ Assume that (1) Mrs. Gross (the victimized neighbor) had seen Elstad and some men she could not identify running from the house, (2) the police were able to identify Elstad's fingerprints on the broken door, and (3) a friend of Elstad had reported to the police that Elstad had told her that he had burglarized the Gross house. Under these circumstances, it would have been entirely appropriate for the police to question Elstad without warnings as part of an effort to ascertain the identity of, and evidence against, his cohorts. Such statements would, of course, be inadmissible against Elstad. But because they already have a case against him, it is eminently sensible to give him use immunity regarding this additional information in order to track down his cohorts.

In addition to situations in which the police forgo evidence against one criminal in order to obtain evidence against cohorts, there are cases in which something other than evidentiary concerns motivates a police officer's question. For example, there may actually be a situation in which the officer wants to insure a "Christian burial."84 More likely, the officer may want to ascertain whether a murder has been committed, if so, where the body has been buried, and, if not, where

at 619. Consequently, his fourth amendment rights may have been violated. See Brown v. Illinois, 422 U.S. 590 (1975). To the extent that they were, my laudatory description of the police conduct would be unwarranted. The court's analysis, however, is predicated on the assumption that Herman's Miranda rights were violated, and it is with this analysis that I disagree.

82. 470 U.S. 298 (1985).

83. The police first interrogated Elstad at his house. As Officer Burke testified,

"I sat down with Mr. Elstad and I asked him if he was aware of why Detective McAllister and myself were there to talk with him. He stated no, he had no idea why we were there. I then asked him if he knew a person by the name of Gross, and he said yes, he did, and also added that he heard that there was a robbery at the Gross house. And at that point I told Mr. Elstad that I felt he was involved in that, and he looked at me and stated, 'Yes, I was there." "

470 U.S. at 301 (quoting app. 19-20). Elstad was then taken to the sheriff's headquarters, where he was advised of his Miranda rights for the first time. He subsequently gave a full statement, which was typed, reviewed and then signed by Elstad. 470 U.S. at 301 . The first confession was elicited without administering Miranda warnings. Nevertheless, the Court held the self-incrimination clause of the fifth amendment does not require the suppression of a confession, made after proper Miranda warnings and a valid waiver of rights, solely because the police had obtained an earlier voluntary but unwarned admission from the suspect.

84. The reference, of course, is to the notorious Williams cases. See Brewer v. Williams, 430 U.S. 387 (1977); Nix v. Williams, 467 U.S. 431 (1984). 
the live kidnap victim has been taken. ${ }^{85}$ Or the officer might really fear that a small child will pick up a discarded gun and kill herself. ${ }^{86}$ To the extent that nonevidentiary motives actually influence the police in these kinds of situations, police should feel free to question, secure in the knowledge that so long as neither the answers nor anything derived from the answers is used against the suspect, the Constitution has not been violated.

Perhaps the most illustrative case to reach the Supreme Court is New York v. Quarles, 87 in which police arrested a suspect in a supermarket, after a rape victim described the suspect and his hiding place. As the police entered the supermarket, Quarles retreated towards the rear of the store until he was run down and arrested by Officer Kraft. Upon capturing Quarles, Kraft holstered his gun and frisked him. Quarles by this time was being guarded by three other officers who were pointing guns at him. After finding no weapon, Kraft handcuffed Quarles and the other officers holstered their guns, whereupon Kraft asked: "Where is the gun?"88 Quarles pointed to some cartons a few feet away and said: "The gun is over there." 89 Kraft then retrieved a loaded revolver from behind the cartons.

The Court unanimously agreed that the police violated no constitutional right of Quarles by ascertaining the location of the gun from him without giving him Miranda warnings.90 It also unanimously agreed that if Quarles' statement were actually compelled, the statement would be inadmissible. ${ }^{91}$ These two steps were correct. Admis-

85. For example, in a case frighteningly similar to Williams that occurred in my home town of Chapel Hill, North Carolina, the District Attorney and defense attorney plea bargained for the defendant to reveal the location of the body in exchange for the prosecutor's not seeking the death penalty.

86. The reference is to Rhode Island v. Innis, 446 U.S. 291, 294-95 (1980), in which a policeman's statement, "God forbid one of them [handicapped children] might find a weapon with shells and they might hurt themselves[]" induced an incriminating response. Whether the safety of children actually motivated the police in that case is debatable. See White, Rhode Island v. Innis: The Significance of a Suspect's Assertion of His Right to Counsel, 17 AM. CRIM. L. REv. 53, 68-69 (1979).

87. 467 U.S. 649 (1984).

88. 467 U.S. at 675 (Marshall, J., dissenting).

89. 467 U.S. at 675.

90. "[W]e believe that this case presents a situation where concern for public safety must be paramount to adherence to the literal language of the prophylactic rules enunciated in Miranda." 467 U.S. at 653 (Rehnquist, J., for the Court). "Miranda has never been read to prohibit the police from asking questions to secure the public safety." 467 U.S. at 664 (O'Connor, J., concurring in part and dissenting in part). "If a bomb is about to explode or the public is otherwise imminently imperiled, the police are free to interrogate suspects without advising them of their constitutional rights. ... All the Fifth Amendment forbids is the introduction of coerced statements at trial." 467 U.S. at 686 (Marshall, J., dissenting, with Brennan and Stevens, JJ.).

91. Justice Rehnquist, writing for the Court, stated:

The dissent curiously takes us to task for "endors[ing] the introduction of coerced selfincriminating statements in criminal prosecutions," and for "sanctioning sub silentio crimi- 
sion of compelled confessions, not police misconduct, is necessary for a Miranda violation. However, by a five to four vote, in an opinion by Justice Rehnquist, the Court went on to hold that the conclusive presumption of coercion which normally follows a failure to give Miranda warnings was inapplicable to a confession obtained in order to preserve the public safety. The Court apparently permitted Quarles' nonMirandized statement to be admitted because a legitimate nonevidentiary motive meant that there had been no police misconduct.

The Court's refusal to follow the Miranda presumption seems strange. As Justice O'Connor understated: "[T]here is nothing about an exigency that makes custodial interrogation any less compelling ...."92 Or, as Justice Marshall put it: "The 'public safety' exception is efficacious precisely because it permits police officers to coerce defendants into making involuntary statements." 93 Indeed, it is difficult to imagine any handcuffed, unarmed man, who would feel free to ignore the urgent request of an armed policeman backed up by three other armed policemen, especially when the policeman has not indicated a willingness to take "no" for an answer by giving Miranda warnings. ${ }^{94}$ Furthermore, the very nature of public safety needs is such that one would expect more police coercion in such a situation than any place else. Consequently, one would think that the public safety situation would be the most appropriate place to apply the $M i$ randa presumption.

The best explanation for the majority's opinion is its conclusion that excluding the evidence would be "penalizing officers for asking the very questions which are the most crucial to their efforts to protect themselves and the public."95 The Court analyzed the case as a police practices case. Since the Court was disinclined to "punish" police for what it saw as appropriate conduct, the Court refused to exclude the evidence. If, however, the majority had understood Miranda as a trial rights case rather than a police practices case, there would have been

nal prosecutions based on compelled self-incriminating statements." Of course our decision today does nothing of the kind. ... [R]espondent is certainly free on remand to argue that his statement was coerced under traditional due process standards. Today we merely reject the only argument that respondent has raised to support the exclusion of his statement, that the statement must be presumed compelled because of Officer Kraft's failure to read him his Miranda warnings.

467 U.S. at 655 n.5 (citations omitted). The four dissenting Justices would have held the statement inadmissible on the basis of presumed coercion. See infra text accompanying notes 92-93.

92. 467 U.S. at 665 (concurring and dissenting opinion).

93. 467 U.S. at 685 (dissenting opinion).

94. If Quarles were reprosecuted, the evidence might be inadmissible as a coerced confession under the fifth amendment. See infra text accompanying notes 146-48. According to the Court, Quarles had not raised the issue at trial, but was free to raise it on appeal. See supra note 91.

95. 467 U.S. at 658 n.7. 
no occasion to talk about "penalizing officers." We do not talk about penalizing Congressmen or penalizing prosecutors when those whom they have compelled to testify are granted use immunity. The problem in Quarles is that the focus on police misconduct prevented the Court from remedying the actual Miranda violation which occurred not when Kraft asked about the gun, but when Quarles' response was admitted as evidence. Of course, the Court did say that if the confession is truly coerced, it is inadmissible. Presumably, in such a case, the Court thinks the police deserve to be "penalized."96 Because in a true emergency, however, the police are, or ought to be, at their coercive best, failure to apply the Miranda presumption seems singularly inappropriate.

If my analysis has been correct, one might wonder about the value of Miranda. The Court has told us that the Miranda rules are not required by the privilege against self-incrimination, but are "prophylactic standards [designed] to safeguard that privilege."97 What value is a prophylactic standard designed to insure compliance by preventing police misconduct, if compliance is not a proper goal of the judiciary? The answer is that the Court has articulated two prophylactic rationales for Miranda. One is designed to insure that no involuntary statements are admitted, even at the cost of excluding some voluntary ones. The other rationale, like the fourth amendment exclusionary rule, is designed to deter noncompliance. The first of these rationales is legitimate; the second is not. 98

The legitimate Miranda prophylactic rationale is as follows: There are a substantial number of confessions obtained during custodial interrogation that are in fact coerced. Because of the secrecy of a custodial interrogation that involves only the police and the suspect, it is extraordinarily difficult to ascertain whether a particular confession is in fact compelled. Furthermore, attempting such ascertainment in every case would be so time consuming that courts, especially the Supreme Court, would be unable to do it. ${ }^{99}$ Consequently, a number of confessions that were in fact compelled would be introduced against defendants. Inasmuch as the privilege against compelled self-incrimi-

96. But see infra text accompanying notes $146-48$.

97. See Michigan v. Tucker, 417 U.S. 433, 446 (1974).

98. For a general discussion of prophylactic rules, see Strauss, The Ubiquity of Prophylactic Rules, 55 U. CHI. L. REv. 190 (1988); Grano, Miranda's Constitutional Difficulties: A Reply to Professor Schulhofer, 55 U. CHI. L. REv. 174 (1988); Grano, Prophylactic Rules in Criminal Procedure: A Question of Article III Legitimacy, 80 Nw. U. L. REv. 100 (1985); Monaghan, The Supreme Court, 1974 Term - Foreword: Constitutional Common Law, 89 HARv. L. REV. 1 (1975).

99. See Miranda, 384 U.S at 475-76; Schulhofer, Reconsidering Miranda, 54 U. CHI. L. REV. 435, 446-53 (1987). 
nation is a fundamental component of our constitutional fabric, it is better for the prosecution to be deprived of a few voluntary statements than to risk convicting a defendant with a compelled self-incriminating statement. ${ }^{100}$ This rule is especially appropriate when at the time of announcing the presumption of coercion, the Court explicitly indicates to the police the precise methodology for overcoming the presumption. Although one could argue that the Miranda rules require the police to give too many ${ }^{101}$ or too few ${ }^{102}$ warnings, those rules seem a reasonable compromise to ensure that compelled self-incrimination is not permitted in the courts of this nation. ${ }^{103}$

The illegitimate prophylactic rationale seeks to deter police violations of Miranda by imposing an exclusionary rule on confessions obtained following such violations. The problem with this approach is that the fifth amendment does not contain an exclusionary rule; it is itself an exclusionary rule. The substantive right is the right not to have compelled confessions used against the confessor at trial. Consequently, the line of cases that have refused to apply Miranda because it would have no impact on police conduct misses the mark. These cases hold that a Miranda-presumed coerced confession is not to be equated with a real coerced confession. Rather, the Miranda-presumed coerced confession is only to be excluded when exclusion would have a significant deterrent effect on police behavior.

The development of this rationale began in Harris v. New York, 104 where the Court allowed statements obtained in violation of Miranda to impeach the defendant's credibility. Without even considering whether Miranda should be analyzed as an exclusionary rule case, the Court held: "Assuming that the exclusionary rule has a deterrent effect on proscribed police conduct, sufficient deterrence flows when the evidence in question is made unavailable to the prosecution in its case in chief." 105 Had the Court viewed these statements as actually rather than presumptively compelled, however, use immunity would have precluded their use, even for impeachment purposes. ${ }^{106}$

100. Cf. In re Winship, 397 U.S. 358 (1970).

101. See Caplan, Questioning Miranda, 38 VAND. L. REV. 1417 (1985); Grano, Selling the Idea To Tell the Truth: The Professional Interrogator and Modern Confession Law (Book Review) 84 MiCH. L. REV. 662 (1986).

102. See Ogletree, Are Confessions Really Good for the Soul?: A Proposal To Mirandize Miranda, 100 HARV. L. REV. 1826 (1987); Schulhofer, supra note 99; White, Defending Miranda: Reply to Professor Caplan, 39 VAND. L. REv. 1, 10, 21 (1986).

103. See Moran v. Burbine, 475 U.S. 412, 424-27 (1986).

104. 401 U.S. 222 (1971).

105. 401 U.S. at 225.

106. See New Jersey v. Portash, 440 U.S. 450 (1979); Mincey v. Arizona, 437 U.S. 385 (1978). Other illustrations of this approach include Michigan v. Tucker, 417 U.S. 433 (1974), in 
An unfortunate byproduct of the Court's focus on deterrence has been to engender unnecessary debate on whether a particular nonapplication of Miranda will weaken its deterrent effect. ${ }^{107}$ Much more significantly, however, the emphasis on this illegitimate Miranda prophylactic has weakened its legitimate prophylactic value. Under the law as it now stands, when the state seeks to impeach a witness with a prior inconsistent confession, ${ }^{108}$ or introduce evidence derived from a confession, ${ }^{109}$ the actual as opposed to the presumptive coerciveness of the confession must be litigated. Consequently, all of the concerns of secret interrogations, inaccurate determinations of compulsion, inadequate judicial time, and the possibility of unconstitutionally compelled confessions contributing to convictions have returned.110 Perhaps this occurrence is inevitable when the Court that construes a prior decision, such as Miranda, grudgingly tolerates rather than openly embraces that decision. ${ }^{11}$ Nevertheless, deterrence analysis has no place in fifth amendment jurisprudence. If the Court cannot accept $\mathrm{Mi}$ -

which the Court allowed the testimony of a witness who would not have been discovered without the confession, and Oregon v. Elstad, 470 U.S. 298 (1985), where the Court upheld a confession that might not have been obtained had it not been for an earlier improperly induced confession. Once again, had the statements been actually rather than presumptively compelled, the derivative evidence would have been excluded under use immunity.

107. For example, in their criticism of Harris, Professors John Hart Ely and Alan Dershowitz spend nearly three full pages meticulously disproving the claim that the Harris result is consistent with the deterrence desired by Miranda. See Ely \& Dershowitz, Harris v. New York: Some Anxious Observations on the Candor and Logic of the Emerging Nixon Majority, 80 YALE L.J. 1198, 1218-21 (1971). Similarly, in Oregon v. Hass, 420 U.S. 714 (1975), Justice Brennan, dissenting from an extension of Harris to a case in which the defendant was questioned after he had invoked his right to counsel, criticized the Court for further weakening the deterrent value of Miranda:

Even after Harris, police had some incentive for following Miranda by warning an accused of his [rights]. If the warnings were given, the accused might still make a statement which could be used in the prosecution's case in chief. Under today's holding, however, once the warnings are given, police have almost no incentive for following Miranda's requirement that "[i]f the individual states that he wants an attorney, the interrogation must cease until an attorney is present." Miranda, [384 U.S.] at 474. If the requirement is followed there will almost surely be no statement since the attorney will advise the accused to remain silent. If, however, the requirement is disobeyed, the police may obtain a statement which can be used for impeachment if the accused has the temerity to testify in his own defense.

420 U.S. at 725 (footnotes omitted).

Because the Court in both Harris and Hass claimed that those decisions did not adversely impact on Miranda's deterrent value, I do not criticize either Professors Ely and Dershowitz or Justice Brennan for challenging those claims. Rather, I question the relevance of the issue.

108. See Oregon v. Hass, 420 U.S. 714 (1975); Harris v. New York, 401 U.S. 222 (1971).

109. See Oregon v. Elstad, 470 U.S. 298 (1985); Michigan v. Tucker, 417 U.S. 433 (1974). Although Elstad suggested that prior Supreme Court decisions had held evidence obtained from a Miranda violation to be admissible against the person questioned, 470 U.S. at 307-08, no Supreme Court case has held that all such evidence is "untainted fruit." At the very least, however, the Court perceives Miranda as having short coattails.

110. See Schulhofer, Confessions and the Court (Book Review), 79 Mich. L. REv. 865 (1981).

111. The opinions in cases like Harris, Tucker, Quarles, and Elstad (discussed above) all read like efforts to explain away or narrow Miranda rather than to embrace it openly. 
randa for its proper fifth amendment value, perhaps it should overrule it. Preferably, it should take that fifth amendment value seriously.

\section{Right TO COUNSEL}

The sixth amendment provides: "In all criminal prosecutions, the accused shall enjoy the right . . . to have the Assistance of Counsel for his defence." 112 This clause is frequently invoked when the police obtain evidence, such as a confession or lineup identification, without counsel. ${ }^{113}$

Cases involving confessions obtained in the absence of counsel bear a surface resemblance to those in which confessions are obtained in violation of Miranda. Indeed, in some cases, the rationales are almost interchangeable. ${ }^{114}$ They do vindicate different interests, however. While Miranda concerns compulsion, the right to counsel cases are concerned with the integrity of the adversarial process. Consequently, they forbid the use of confessions deliberately elicited in the absence of counsel, even under circumstances that are neither actually nor presumptively compelling. ${ }^{115}$

In Massiah v. United States, ${ }^{116}$ the Court suggested, but stopped short of holding, that the sixth amendment's right to counsel permits deliberately eliciting confessions, so long as they are not used against the person from whom they were elicited. ${ }^{117}$ The opinion indicated a willingness to analyze the sixth amendment as a procedural right, prohibiting the use of unconstitutional evidence. In line with this reasoning but more explicitly, the Court has clearly held that the right to

112. U.S. CoNST, amend. VI.

113. See, e.g., Massiah v. United States, 377 U.S. 201 (1964) (confession); United States v. Wade, 388 U.S. 218 (1967) (lineup identification).

114. See, e.g., Brewer v. Williams, 430 U.S. 387 (1977). See generally Kamisar, Brewer v. Williams, Massiah and Miranda: What Is Interrogation? When Does It Matter?, 67 GEo. L.J. 1 (1978).

115. For example, in Massiah v. United States, 377 U.S. 201 (1964), and Maine v. Moulton, 474 U.S. 159 (1985), the confessions were elicited by the defendant's own cohort; and in United States v. Henry, 447 U.S. 264 (1980), the elicitor was a fellow inmate. But cf. Kuhlman v. Wilson, 477 U.S. 436 (1986).

116. 377 U.S. 201 (1964).

117.

We do not question that in this case, as in many cases, it was entirely proper to continue an investigation of the suspected criminal activities of the defendant and his alleged confederates, even though the defendant had already been indicted. All we hold is that the defendant's own incriminating statements, obtained by federal agents under the circumstances here disclosed, could not constitutionally be used by the prosecution as evidence against him at his trial.

Massiah, 377 U.S. at 207 (emphasis in original). Because the Court did not explicitly approve eliciting statements as one of the "entirely proper" means of investigation, I have employed the cautionary textual language: "suggested, but stopped short of holding . ...." 
counsel exists to insure the fairness of the trial. The right only applies to confrontations occurring after the onset of formal judicial proceedings. ${ }^{118}$ Even then, if the stage is not critical, the right to counsel will not apply. Relying on such logic, the Court has held the right to counsel to be inapplicable to blood tests, ${ }^{119}$ post-indictment handwriting exemplars, ${ }^{120}$ and even post-indictment pictorial lineups. ${ }^{121}$ Consequently, it seems likely that, if pushed, the Court would hold that the deliberate elicitation of a post-indictment confession, if the confession is not introduced at trial, does not occur during a critical stage of the proceedings, and therefore does not constitute a violation of the sixth amendment. 122

Ascertaining the nature of the right to counsel is especially important when the state claims a legitimate justification for deliberately eliciting a confession. Only in this way can a court assess when the right has been violated. For example, in Maine v. Moulton, ${ }^{123}$ Moulton, and his codefendant Colson, had been indicted for four theft offenses (hereinafter called series $A$ crimes). Colson, represented by counsel, voluntarily confessed to the police that he and Moulton had committed the series $A$ crimes. In addition, Colson implicated himself and Moulton in several other crimes and indicated that Moulton had discussed killing a potential witness against him (series $B$ crimes). Colson agreed to be wired with a transmitting device and, while so wired, deliberately elicited incriminating statements from Moulton regarding both series $A$ and series $B$ crimes. The state argued that inasmuch as it had a legitimate interest in deliberately eliciting incriminating statements about series $B$ crimes, it was justified in its actions. Because it could not elicit information about series $B$ crimes without also eliciting information about series $A$ crimes, the state contended that that information also was properly obtained, and should be admissible.

The Court had several potential solutions to the case. At one extreme, it could have held that since the right to counsel had already attached for series $A$ crimes, the police (through Colson) had no right to deliberately elicit incriminating statements about them. If the state could not elicit incriminating statements about series $B$ crimes without

118. Compare Kirby v. Illinois, 406 U.S. 682 (1972), with Moore v. Illinois, 434 U.S. 220 (1977).

119. Schmerber v. California, 384 U.S. 757, 765-66 (1966).

120. Gilbert v. California, 388 U.S. 263, 266-67 (1967).

121. United States v. Ash, 413 U.S. 300 (1973).

122. Cf. Ransom v. City of Philadelphia, 311 F. Supp. 973, 974 (E.D. Pa. 1970).

123. 474 U.S. 159 (1985). 
also eliciting statements about series $A$ crimes, it would be obligated to forgo eliciting statements about any crime. By eschewing that course of action and deliberately eliciting statements about all crimes, the police violated Moulton's sixth amendment rights. Consequently, not only is all 'of the evidence inadmissible, but Moulton should prevail in a civil rights action against the police who violated his sixth amendment rights. Such an approach would view the sixth amendment as a substantive protection against obtaining evidence in this manner, and would impose a remedial exclusionary rule on any of the evidence. No Justice maintained such a position.

Speaking for the Court, Justice Brennan appeared to hold that the state violated Moulton's sixth amendment rights when it elicited statements about his series $A$ crimes: "Accordingly, the Sixth Amendment is violated when the State obtains incriminating statements by knowingly circumventing the accused's right to have counsel present in a confrontation between the accused and a state agent."124 On the other hand, it upheld the state's conduct in eliciting statements about series $B$ crimes because the statements had not been unconstitutionally acquired. The net result of the holdings was to exclude the tainted statements relating to series $A$ crimes, but admit the properly obtained statements relating to series $B$ crimes. Although the opinion seemed predicated on the impropriety of certain police practices, it failed to articulate a clear standard of behavior, making it extremely difficult for a lawyer to tell a police officer in the Moulton situation whether or not he was acting constitutionally.

Chief Justice Burger, for the dissent, had no difficulty with this question. In his view, the need to obtain Moulton's statements about series $B$ crimes legitimated the entire process. As he saw it, the right to counsel did not attach, thereby leaving no unconstitutional behavior to deter, and rendering both series $A$ and series $B$ statements admissible. Indeed, Burger went further and argued that even if the right to counsel did apply to the series $A$ statements, the exclusionary rule should not be invoked to preclude their use: "Like searches in violation of the Fourth Amendment, the 'wrong' that the Court condemns was 'fully accomplished' by the elicitation of comments from the defendant and 'the exclusionary rule is neither intended nor able to cure the invasion of the defendant's rights which he has already suffered." "125 Obviously, the Chief Justice believed that obtaining rather

124. 474 U.S. at 176 (emphasis added).

125. 474 U.S. at 191 (quoting United States v. Leon, 468 U.S. 897, 906 (1974)). 
than using the evidence was the wrong protected against by the sixth amendment.

The Court should have held that none of the police conduct was improper. In view of the need to obtain series $B$ statements, there is no reason to cast doubt on the propriety of the procedure. ${ }^{126}$ On the other hand, there is every reason to take Moulton's sixth amendment rights seriously. Because the sixth amendment is a procedural right that applies only to critical stages of criminal proceedings, it can be fully honored by disallowing the evidence for series $A$ crimes. By so holding, the stage at which the statements were obtained becomes noncritical, thereby rendering counsel unnecessary. Of course, the series $B$ statements should be admissible because there was no right to counsel regarding the series $B$ crimes.

Although this result is identical to that reached by the Court, it reaches it through a more direct route. Unlike the Court's opinion, it casts no aspersions on the legality of the police conduct. It allows the Court to vindicate legitimate governmental interests without ignoring serious constitutional rights. Most importantly, it renders analysis of the exclusionary rule absolutely irrelevant. Any statement deliberately elicited from a suspect after the commencement of adversary proceedings would automatically be inadmissible if the suspect were without the aid of counsel. The justification for disallowing such evidence would not be the "exclusionary rule," but the sixth amendment's rules governing fair trials.

In view of the obviously procedural nature of the right to counsel, where did the fourth amendment exclusionary remedy type of analysis originate? The first Supreme Court case to employ it appears to have been Gilbert v. California, ${ }^{127}$ in which the Court held that a post-indictment lineup identification obtained in the absence of counsel was per se inadmissible: 128

That testimony is the direct result of the illegal lineup "come at by the exploitation of [the primary] illegality." The State is therefore not entitled to show that the testimony had an independent source. Only a per se exclusionary rule as to such testimony can be an effective sanction to assure that law enforcement authorities will respect the accused's consti-

126. Under my concept of a Utopian world, the government's electronic recording (through Colson) of Moulton's statements without a warrant would constitute a violation of the fourth amendment. See Loewy, supra note 18, at 1252-54. Unfortunately, the law is otherwise. See United States v. White, 401 U.S. 745 (1971). In any event, if the police had obtained a warrant (which seems feasible in this case), the sixth amendment problems would remain.

127. 388 U.S. 263 (1967).

128. Three years earlier, a dissenting opinion had criticized the Court for "[a]pplying the new exclusionary rule" when the Court refused to admit a confession on sixth amendment grounds. Massiah v. United States, 377 U.S. 201, 211 (1964) (White, J., dissenting). 
tutional right to the presence of counsel at the critical lineup. In the absence of legislative regulations adequate to avoid the hazards to a fair trial which inhere in lineups as presently conducted, the desirability of deterring the constitutionally objectionable practice must prevail over the undesirability of excluding relevant evidence. ${ }^{129}$

Despite this language, the Court, in the companion case of United States v. Wade, ${ }^{130}$ clearly and explicitly indicated that the purpose of the counsel at the lineup was to insure a fair trial. ${ }^{131}$ Consequently, rather than lamenting the loss of relevant evidence, the Gilbert Court should have applauded the exclusion of potentially prejudicial and misleading evidence. More importantly, if the right to counsel exists to insure a fair trial, consideration of the right should depend on the state's introduction of illegal evidence. For example, a district attorney with six confirmed witnesses against the defendant might hold a post-indictment lineup without counsel to see if a seventh witness could also identify defendant. But if the district attorney did not use the seventh witness, the defendant's right to a fair trial would not have been violated, and the right to counsel never would have attached. The concept of "deterring the constitutionally objectionable practice" becomes meaningless since nothing unconstitutional occurs until illegal evidence is used.

But in his criticism of Gilbert, Professor Joseph Grano would have expanded the ill-conceived exclusionary remedy rather than rights analysis:

In the fourth amendment context, years of fervent debate preceded the Court's conclusion that the exclusionary rule provides the most effective safeguard against police illegality. Yet, in establishing a right to counsel at lineups, a right not presaged in a single jurisdiction, the court, without the benefit of debate, apparently assumed that no other remedy would suffice. The Court did not even specify the possible alternatives being rejected as it had done in the search and seizure area. ${ }^{132}$

One reason the Court did not specify alternatives was that a proce-

129. 388 U.S. at 272-73 (quoting Wong Sun v. United States, 371 U.S. 471, 488 (1963)).

130. 388 U.S. 218 (1967).

131. The Wade Court wrote:

It is central to that (constitutional) principle that ... the accused is guaranteed that he need not stand alone against the State at any stage of the prosecution, formal or informal, in court or out, where counsel's absence might derogate the accused's right to a fair trial. The security of that right is as much the aim of the right to counsel as it is of the other guarantees of the Sixth Amendment - the right of the accused to a speedy and public trial by an impartial jury, his right to be informed of the nature and cause of the accusation, and his right to be confronted with the witnesses against him and to have compulsory process for obtaining witnesses in his favor.

388 U.S. at 226-27 (footnotes omitted).

132. Grano, Kirby, Biggers, and Ash: Do Any Constitutional Safeguards Remain Against the Danger of Convicting the Innocent?, $72 \mathrm{MrCH}$. L. REv. 717, 791 (1974) (footnotes omitted). 
dural wrong can have only one remedy. Grano's suggestion of civil suits or criminal prosecutions against police officers ${ }^{133}$ would not wash if there were no violation until the identification was introduced. Even then, it would be the prosecutor and not the policeman who committed the wrong, and prosecutors have absolute immunity from suit. ${ }^{134}$ Although the Court's "deterring the constitutionally objectionable practice"135 language provided the impetus for Grano's criticism, the Court, unlike Grano, intuitively recognized that if counsel at a lineup were necessary to preserve a fair trial, there could be no alternative to exclusion. ${ }^{136}$

Grano further argues that the Wade/Gilbert right is less basic to a free society than freedom from unreasonable searches and seizures. Consequently, he contends that there is less reason to apply the exclusionary rule when the right to counsel is violated. ${ }^{137}$ This analysis is identical to and flawed in the same way as that which describes fourth amendment rights as second class to the extent that their exclusionary rule is not coterminous with coerced confessions. ${ }^{138}$ With both fourth and sixth amendment rights the issue is the nature of the right, not its importance. While fourth amendment rights are basically substantive, ${ }^{139}$ fifth and sixth amendment rights are procedural. Consequently, when the Court automatically excludes identifications obtained in contravention of the Wade/Gilbert rule and simultaneously subjects fourth amendment violations to an exclusionary cost/ benefit analysis, it is not holding that Wade/Gilbert is more important, only that it is different.

\section{COERCED CONFESSIONS}

In Malloy v. Hogan, the Supreme Court clearly held that coerced confessions violate the privilege against self-incrimination. ${ }^{140}$ Thus, the use of such a confession constitutes the primary constitutional violation. ${ }^{141}$ Indeed, unlike a Miranda violation, which the Court views

133. Id. at 791 n.460.

134. See Imbler v. Pachtman, 424 U.S. 409 (1976). But cf. Harlow v. Fitzgerald, 457 U.S. 800, 811 n.16 (1982).

135. Gilbert v. California, 388 U.S. 263, 273 (1967).

136. This is not to say that Gilbert necessarily is a good rule. One could certainly argue that the right to counsel at a lineup is not necessary to insure a fair trial. If one accepts the Court's premise about the necessity of counsel, however, the evidence must be excluded.

137. Grano, supra note 132 , at 792-93.

138. See supra text accompanying notes 22-23.

139. See supra Part 1 .

140. 378 U.S. 1, 6 (1964).

141. Prior to Malloy, the purposes of excluding coerced confessions seemed to be (1) the integrity of the fact-finding process, and (2) deterring unlawful police behavior. See generally 
as only conclusively presumed compulsion, ${ }^{142}$ coerced confessions are actually compelled within the meaning of the fifth amendment. Consequently, no derivative use, such as impeachment, is permissible. ${ }^{143}$

Unlike confessions obtained from Miranda or sixth amendment violations, however, some coerced confessions are also obtained unconstitutionally. For an extreme example, consider Brown $v$. Mississippi, ${ }^{144}$ in which the defendants were severely beaten and were threatened with continuous beatings unless they confessed. Such police conduct is clearly wrong in itself, regardless of whether any confession is used or even obtained. Consequently, defendants like Brown, but unlike Miranda, can sue the police officers for violating their constitutional rights. ${ }^{145}$

Not all coerced confessions are unconstitutionally obtained, however. For example, assume that after remand in New York $v$. Quarles, ${ }^{146}$ the New York court were quite sensibly to hold that because Quarles was surrounded by four armed policemen who had just handcuffed him, his confession was coerced. ${ }^{147}$ Such a holding would not be predicated on any constitutional impropriety by the police. Because Quarles had just committed rape while armed with a gun, the police were certainly justified in threatening deadly force when arresting him and in handcuffing him upon arrest. ${ }^{148}$ Nevertheless, constitutionally proper conduct did compel the defendant to make incriminating statements. Consequently, the best solution is to disallow any civil suit by Quarles because the police did not violate his rights in obtaining the evidence. At the same time, a court should exclude the evidence because admitting it would violate Quarles' fifth amendment rights.

Although ascertaining whether the confessions were unconstitutionally obtained was easy in Brown and Quarles, most cases fall between these extremes, and the determination is much more difficult. Obtaining the coerced confession, without more, is not a violation.

Kamisar, What Is an Involuntary Confession? Some Comments on Inbau and Reid's Criminal Interrogation and Confessions (Book Review), 17 RuTGERS L. REv. 728 (1963).

142. See supra text accompanying notes 91-111.

143. See Mincey v. Arizona, 437 U.S. 385 (1978).

144. 297 U.S. 278 (1936). 1968).

145. See United States ex rel. Brzozowski v. Randall, 281 F. Supp. 306, 311-12 (E.D. Pa.

146. 467 U.S. 649 (1984); see supra text accompanying notes 87-96 (discussing New York v. Quarles).

147. Whether such a ruling was ever made does not appear in the subsequent history of the case.

148. See Tennessee v. Garner, 471 U.S. 1 (1985). 
The violation occurs when some other right is violated in the process. In Brown, for example, the police clearly imposed punishment without due process of law, and cruel and unusual punishment at that. ${ }^{149}$ For this reason, I will designate cases like Brown as "coerced-confessionplus" cases.

An example of a close case is Haynes $v$. Washington, ${ }^{150}$ a pre-Miranda case in which police held Haynes incommunicado until he signed a written confession. Although Haynes had already orally confessed to the crime, ${ }^{151}$ the police booked him for investigation, rather than formally arresting him. In Spokane, Washington, at that time, a person booked for investigation was not permitted to make phone calls or have visitors. As a result, police were able to condition Haynes' request to telephone his wife so that she could arrange for a lawyer on his signing a written confession. Because Haynes was told that he would be held incommunicado indefinitely until he signed the confession, the Court found his confession to be involuntary.

Although the Court described the police behavior as "official misconduct [that] cannot but breed disrespect for the law, as well as for those charged with its enforcement,"152 it was not clear what the nature of the constitutional violation was. I suppose that at some point incommunicado detention might constitute punishment without due process of law, or even cruel and unusual punishment. ${ }^{153}$ More likely, the sixteen hours between booking and confession constituted an unreasonable seizure under the fourth amendment. One arrested without a warrant is required to be taken to a magistrate without unnecessary delay. ${ }^{154}$ Given the willfulness of the delay, Haynes' fourth amendment rights were probably violated. ${ }^{155}$ Under these circumstances Haynes would qualify as a coerced-confession-plus case. He would be entitled not only to have the written confession excluded, but to bring a civil suit against the police.

149. See United States v. Williams, 341 U.S. 70, 101 (1951); cf. Screws v. United States, 325 U.S. 91 (1945).

150. 373 U.S. 503 (1963).

151. His two prior oral confessions were introduced at trial, and not challenged on appeal. 373 U.S. at 505.

152. 373 U.S. at 519.

153. Cf. Adams v. Carlson, 488 F.2d 619 (7th Cir. 1973) (inmates sentenced to indefinite segregation without advance notice of charges against them were denied due process); Sostre v. Rockefeller, 312 F. Supp. 863 (S.D.N.Y. 1970) (inmate's sentence of indefinite solitary confinement for preparing a legal motion for codefendant was cruel and unusual punishment), modified sub nom. Sostre v. McGinnis, 442 F.2d 178 (2d Cir. 1971), cert. denied, 404 U.S. 1049, 405 U.S. 978 (1972).

154. See Gerstein v. Pugh, 420 U.S. 103 (1975).

155. Which, of course, may be an independent reason for excluding the confession. See Thomas, The Poisoned Fruit of Pretrial Detention, 61 N.Y.U. L. REv. 413 (1986). 
Rogers v. Richmond, ${ }^{156}$ another pre-Miranda case, is a close case that would probably be decided the other way. Rogers, who presumably had been lawfully arrested, ${ }^{157}$ was transported without court order from his jail to the prosecutor's office. There he was questioned by several police officers for six hours, at which time one of the officers threatened to bring Rogers' ill wife in for questioning if he did not confess. Following another hour of silence from Rogers, the police officer indicated that he was going to bring in Rogers' wife, and Rogers confessed. The next morning while Rogers was held incommunicado pursuant to a coroner's order, an attorney who came to see him was denied access. Shortly thereafter, Rogers was transported to the county courthouse where, pursuant to questions from the coroner, he again confessed. The Supreme Court held the confessions to be inadmissible, emphasizing the procedural importance of not relying on words coerced from defendant to convict. ${ }^{158}$

Finding a basis for Rogers' claim against police for unconstitutionally obtaining the evidence is more difficult than it was in Haynes. Transporting Rogers from jail to the prosecutor's office may have been a violation of Connecticut law, but it would not seem to implicate the fourth amendment. Similarly, denying counsel access to Rogers for the relatively brief time that Rogers was held incommunicado would not seem to be a violation of his right to counsel. ${ }^{159}$ Even if Rogers' right to counsel had attached, 160 the brief incommunicado period would not likely give rise to a substantive law suit against the police as opposed to an additional procedural reason for excluding the confession from evidence.

Rogers' other substantive claim would be based on the threat to arrest his wife. Certainly, if she had been arrested without probable cause, she would have a law suit against the police. Regardless of the resolution of that issue, it is unlikely that Rogers could sue. He would be claiming that the mere threat constituted a violation of his constitutional rights. What rights? Even if he could persuade a court that his psychological well-being constituted life, liberty, or property, it is un-

\section{365 U.S. 534 (1961).}

157. At least nothing to the contrary appears in the case.

158. "[O]urs is an accusatorial and not an inquisitorial system - a system in which the State must establish guilt by evidence independently and freely secured and may not by coercion prove its charge against an accused out of his own mouth." 365 U.S. at 541.

159. Cf. Moran v. Burbine, 475 U.S. 412 (1986) (falsely telling counsel that the suspect was not being questioned neither violates suspect's constitutional rights, nor requires exclusion of the subsequent confession).

160. This point had not been focused upon because the Court's jurisprudence had not yet developed a special time at which the right to counsel attached. 
likely that a court would find the police conduct to have been so outrageous as to violate due process. ${ }^{161}$ As a result, Rogers probably represents a coerced confession case in which the confession was unconstitutionally used, but not unconstitutionally obtained.

In cases like Rogers, nobody other than the defendant should have standing to challenge the confession. For example, if Rogers had implicated his brother and led the police to physical evidence implicating both him and his brother, the evidence should be admissible against his brother. In this regard, the situation is identical to confessions obtained in violation of Miranda warnings. ${ }^{162}$ Since the evidence would have been constitutionally obtained, there is nothing improper about using it against the brother. None of the brother's rights would have been violated. The only possible constitutional wrong would be the use of the evidence against Rogers.

In coerced-confession-plus cases, on the other hand, it is arguable that third parties should have standing to challenge the confessions. Because such confessions are unconstitutionally obtained, courts should minimize police incentive to obtain them. Excluding the evidence against third parties would certainly reduce police incentive to act unconstitutionally. Unfortunately, to the extent that the plus in a coerced-confession-plus case is a fourth amendment violation, as it was in Haynes, the Court's fourth amendment exclusionary rule jurisprudence would probably deny third-party standing. ${ }^{163}$

Suppose the case is more like Brown. For example, in People v. Portelli, ${ }^{164}$ the police, while investigating the murder of two of their comrades, questioned Richard Melville, a man who they believed had information implicating Portelli. Melville refused to incriminate Portelli until the police subjected him to Brown-type torture, at which point he admitted that Portelli had confessed to the entire crime. During Portelli's trial, Melville testified that what he had told the police was true, but that he would not have provided the information had he not been tortured. The New York Court of Appeals, while condemning the police behavior, allowed Melville's testimony and upheld Portelli's conviction that rested upon it.

Assuming that the case were in the Supreme Court and that Mel-

161. Cf. Hampton v. United States, 425 U.S. 484 (1976).

162. See supra text accompanying notes $56-86$.

163. See supra text accompanying notes $26-29,39-43$.

164. 15 N.Y.2d 235, 205 N.E.2d 857, 257 N.Y.S.2d 931 (1965), cert. denied, 382 U.S. 1009 (1966). 
ville's testimony could not be purged of the original taint, ${ }^{165}$ should the testimony be excluded? Unless the fourth amendment exclusionary rule cases could be distinguished, exclusion would seem inappropriate. Perhaps the Court could analogize this situation to the old Wolf/Rochin rules. ${ }^{166}$ Under these rules unconstitutionally obtained evidence was admissible even against the victim of the search, but evidence obtained in a manner that "shocked the conscience"167 was inadmissible against the victim. The Court could retain this hierarchy by holding that in most instances evidence obtained in violation of the fourth amendment is inadmissible against only the victim of the search, but that evidence obtained in a manner that shocks the conscience is inadmissible against anybody.

This solution is not problem-free. One reason that the Wolf/ Rochin dichotomy was abandoned was the unmanageability of the standard. ${ }^{168}$ Furthermore, excluding some, but not other, unlawfully obtained evidence at the behest of third parties really would create a hierarchy of constitutional rights. ${ }^{169}$ On the other hand, the right to be free from police torture may in fact be more important than the right to be free from unreasonable searches and seizures. Although I would be the last to deprecate the importance of the fourth amendment, the right to be secure from unreasonable searches and seizures simply is not as fundamental as the right to be free from torture. 170 Thus, despite the Court's unwillingness to recognize third-party standing to deter unconstitutional searches and seizures, it might allow such

165. Witness testimony is more easily purged of taint than other types of evidence. See United States v. Ceccolini, 435 U.S. 268 (1978); cf. Michigan v. Tucker, 417 U.S. 433 (1974).

166. Wolf v. Colorado, 338 U.S. 25 (1949); Rochin v. California, 342 U.S. 165 (1952).

167. 342 U.S. at 172.

168. Concurring in Mapp v. Ohio, 367 U.S. 643 (1961), which overruled Wolf, Justice Black observed:

In concurring [in Irvine v. California, 347 U.S. 128 (1954)], Mr. Justice Clark emphasized the unsatisfactory nature of the Court's "shock-the-conscience test," saying that this "test" "makes for such uncertainty and unpredictability that it would be impossible to foretell other than by guesswork - just how brazen the invasion of the intimate privacies of one's home must be in order to shock itself into the protective arms of the Constitution." [347 U.S. at 138] ....

... Finally, today, we clear up that uncertainty. As I understand the Court's opinion in this case, we again reject the confusing "shock-the-conscience" standard of the Wolf and Rochin cases and, instead, set aside this state conviction in reliance upon the precise, intelligible and more predictable constitutional doctrine enunciated in [Boyd v. United States, 116

U.S. 616 (1886)].

367 U.S. at $665-66$.

169. Compare text accompanying notes 19-20 and notes 129-31.

170. I suppose that a rough analogy might be drawn between being a burglary victim and a rape victim. One returning to a burglarized home surely must feel a sense of violation, but not at the level felt by a rape victim. 
standing to deter the most flagrant forms of obtaining coerced confessions.

\section{CONCLUSION}

Whether evidence is unconstitutionally obtained or unconstitutionally used makes a difference. If the only constitutional wrong inheres in using the evidence, the Court has no business considering concepts of deterrence. The Court should prohibit only use of such evidence. Conversely, when obtaining evidence is the constitutional wrong, exclusion should be subjected to a cost/benefit analysis. If allowing third-party standing would deter the objectionable practice, such standing should be permitted. It is immaterial whether the third party's rights were violated because redress of individual rights is not the basis for exclusion.

One important problem which this article has identified is the Court's frequently cavalier indifference to the nature of the problem before it. Unless the Court is willing to focus on why it excludes evidence, it will continue to misanalyze problems involving police-obtained evidence. Perhaps of greatest importance, the Court ought to understand what it is doing. 